\title{
Mineralogy affects geoavailability, bioaccessibility and bioavailability of zinc
}

\section{Citation}

Molina, Ramon M., Laurel A. Schaider, Thomas C. Donaghey, James P. Shine, and Joseph D. Brain. 2013. "Mineralogy Affects Geoavailability, Bioaccessibility and Bioavailability of Zinc." Environmental Pollution 182 (November): 217-224. doi:10.1016/j.envpol.2013.07.013.

\section{Published Version}

doi:10.1016/j.envpol.2013.07.013

\section{Permanent link}

http://nrs.harvard.edu/urn-3:HUL.InstRepos:30085119

\section{Terms of Use}

This article was downloaded from Harvard University's DASH repository, and is made available under the terms and conditions applicable to Other Posted Material, as set forth at http:// nrs.harvard.edu/urn-3:HUL.InstRepos:dash.current.terms-of-use\#LAA

\section{Share Your Story}

The Harvard community has made this article openly available.

Please share how this access benefits you. Submit a story.

Accessibility 


\title{
Mineralogy affects geoavailability, bioaccessibility and bioavailability of zinc
}

\author{
Ramon M. Molina ${ }^{a,{ }^{*}}$, Laurel A. Schaider ${ }^{b}$, Thomas C. Donagheya, James P. Shine ${ }^{b}$, and \\ Joseph D. Brain ${ }^{\mathrm{a}}$ \\ aprogram in Molecular and Integrative Physiological Sciences, Harvard School of Public Health, \\ 665 Huntington Avenue, Boston, MA 02115, USA \\ bProgram in Exposure, Epidemiology and Risk, Department of Environmental Health, Harvard \\ School of Public Health, 665 Huntington Avenue, Boston, MA 02115, USA
}

\begin{abstract}
We correlated mineralogical and particle characteristics of Zn-containing particles with $\mathrm{Zn}$ geoavailability, bioaccessibility, and bioavailability following gavage and intranasal (IN) administration in rats. We compared samples of $\mathrm{Zn} / \mathrm{Pb}$ mine waste and five pulverized pure-phase $\mathrm{Zn}$ minerals $(<38 \mu \mathrm{m})$. Particles were neutron-activated to produce radioactive ${ }^{65} \mathrm{Zn}$. We assessed geoavailability using sequential extractions and bioaccessibility using in vitro extraction tests simulating various $\mathrm{pH}$ and biological conditions. $\mathrm{Zn}$ in vivo bioavailability and in vitro bioaccessibility decreased as follows: mine waste $>$ hydrozincite $>$ hemimorphite $>$ zincite $\approx$ smithsonite $\gg$ sphalerite. We found significant correlations among geoavailability, bioaccessibility and bioavailability. In particular, Zn bioavailability post-gavage and post-IN was significantly correlated with bioaccessibility in simulated phagolysosomal fluid and gastric fluid. These data indicate that solid phase speciation influences biological uptake of $\mathrm{Zn}$ and that in vitro tests can be used to predict $\mathrm{Zn}$ bioavailability in exposure assessment and effective remediation design.
\end{abstract}

\section{Keywords}

zinc; metal speciation; bioaccessibility; bioavailability; sequential extractions; physiologicallybased extraction tests

\section{Introduction}

Remediation of contaminated sites requires accurate assessments of risk, yet total contaminant concentrations alone are often poor predictors of uptake and toxicity. Human health risks from contaminants are determined by inherent chemical toxicity, extent of exposure and contaminant bioavailability (fraction of a contaminant in exposure media that can be absorbed by organisms). Thus, evaluating bioavailability can improve dose estimation from exposure assessment (Kobayashi and Okamura, 2005; Milton and Johnson,

(C) 2013 Elsevier Ltd. All rights reserved.

*Corresponding Author: Ramon M. Molina, Harvard School of Public Health, Department of Environmental Health, Program in Molecular and Integrative Physiological Sciences, 665 Huntington Avenue, Boston, MA 02115, USA., Phone: 1-617-432-2311, Fax: 1-617-432-4710, rmolina@hsph.harvard.edu.

Publisher's Disclaimer: This is a PDF file of an unedited manuscript that has been accepted for publication. As a service to our customers we are providing this early version of the manuscript. The manuscript will undergo copyediting, typesetting, and review of the resulting proof before it is published in its final citable form. Please note that during the production process errors may be discovered which could affect the content, and all legal disclaimers that apply to the journal pertain. 
1999; Ruby et al., 1996). Metals are common contaminants at mining and other contaminated locations. Children are especially vulnerable to metal-contaminated soils and indoor dust. Hand-to-mouth and inhalation exposures in playgrounds and home environments are common.

In addition to bioavailability, metal mobility in the environment and biological uptake are influenced by two other related parameters: geoavailability and bioaccessibility. Geoavailability describes the release of metals from solid phases under environmentally relevant conditions. It is the fraction of total metals that can be released to the biosphere through mechanical, chemical and biological processes (Smith, 2007). Bioaccessibility describes the ability of a metal to be solubilized in a biological fluid after ingestion, such as gastric fluid (following oral ingestion) or phagolysosomal fluid (following macrophage uptake after inhalation).

Multiple mechanisms control absorption of particle-bound metals. Oral bioavailability is influenced by physiological factors such as fasted/fed state, associated motility, gastric emptying, intestinal transit time, variability in gastrointestinal (GI) contents and nutritional status (Amidon et al., 1995). For instance, iron (Fe) status regulates expression of divalent metal transporter 1 (DMT1), which mediates absorption of Fe and many other divalent metals such as manganese (Mn), zinc ( $\mathrm{Zn})$, cadmium (Cd), and lead (Pb) (Au et al., 2008). In the respiratory tract, inhaled airborne particles may be deposited depending on their aerodynamic size. The majority $(92 \%)$ of larger particles $(>8 \mu \mathrm{m})$ deposit in nasal passages and upper airways, while inhaled smaller particles ( $\left.\_\mu \mathrm{m}\right)$ deposit in the deep lung (93$97 \%$ ) where they are phagocytized by macrophages (Brain and Valberg, 1979; Heyder and Svarten, 2002).

Bioavailability also varies widely depending on properties of the metal, metal speciation (distribution among various chemical forms), particle size, morphology, and solubility. Metal sulfides and some other primary metal ores tend to have low bioavailability (Ruby, 2004). However, metal ores undergo temporal shifts in speciation that can affect bioavailability. For example, weathering of sulfide minerals in the presence of oxygen can result in speciation changes and the formation of secondary mineral phases that often have greater bioavailability than the parent ore. Metals can also decrease in bioavailability as they become more strongly incorporated into the soil matrix. Temporal variability in metal bioavailability highlights the value of repeated sampling over time.

In vivo determination of metal bioavailability in animal models is time-consuming and expensive. Moreover, the results must be extrapolated to humans. Thus, simpler in vitro bioaccessibility tests to estimate bioavailability would be valuable. Several studies have estimated oral bioavailability of metals in contaminated soils and mine wastes using in vitro tests with a single extraction or series of extractions designed to mimic the GI system (Bradham et al., 2011; Casteel et al., 2006; Juhasz et al., 2009a; Juhasz et al., 2009b; Navarro et al., 2006; Ruby et al., 1996; Schroder et al., 2004). These studies concluded that the characteristics of each metal (Navarro et al., 2006), pH of the extraction solution (Juhasz et al., 2009a; Juhasz et al., 2009b; Ruby et al., 1996), mineralogical composition of samples (Bradham et al., 2011; Navarro et al., 2006), matrix properties and presence of other organic or inorganic components (Casteel et al., 2006) significantly influenced bioaccessibility.

Validation of in vitro tests as predictors of bioavailability requires evaluating both bioavailability and bioaccessibility on the same materials. Correlations between bioaccessibility and bioavailability have been established for Cd (Juhasz et al., 2010; Schilderman et al., 1997), Pb (Casteel et al., 2006; Kelley et al., 2002; OSWER, 2004; Ruby et al., 1996) and As (Bradham et al., 2011; Juhasz et al., 2009b). Studies of Pb- and As- 
contaminated soils showed that in vitro extraction results successfully predicted $\mathrm{Pb}$ bioavailability in rats, but over-predicted As bioavailability in rabbits and primates (Ruby et al., 1996). Bioaccessibility of $\mathrm{Cd}$ in contaminated soils extracted in simulated gastric or intestinal fluids was significantly correlated with relative bioavailable $\mathrm{Cd}$ in swine (Schroder et al., 2004).

Less is known about relationships between bioaccessibility and bioavailability for micronutrient metals such as $\mathrm{Zn}, \mathrm{Cu}$ and $\mathrm{Mn}$. While the consequences of $\mathrm{Zn}$ deficiency are well known (Otten et al., 2006), $\mathrm{Zn}$ is also among the top 100 hazardous substances on the U.S. Agency for Toxic Substances and Disease Registry's Substance Priority List (ATSDR, 2012). Toxicity from excessive intake of $\mathrm{Zn}$ is increasingly recognized, including inhalation of zinc oxide fumes in workplaces or polluted environments (El Safty et al., 2008).

Consequences include $\mathrm{Cu}$ deficiency, immune dysfunction, anemia and other hematological abnormalities (Fosmire, 1990). To our knowledge, there have been no systematic comparisons of $\mathrm{Zn}$ bioaccessibility and bioavailability across a range of chemical forms and routes of exposure.

The goals of this study were to determine whether Zn bioavailability and bioaccessibility are influenced by mineralogy and particle characteristics and the extent to which these in vitro bioaccessibility tests and geochemically-based sequential extractions may predict in vivo bioavailability. We determined $\mathrm{Zn}$ geoavailability, in vitro bioaccessibility, and in vivo bioavailability following gavage and intranasal administration of five $\mathrm{Zn}$ minerals and a $\mathrm{Zn}$ rich mine waste sample. These exposure pathways were selected since larger airborne particles from piles of mine wastes are more likely deposited in the nose than in the lungs and are likely to be ingested via hand-to-mouth transfer, especially by children playing in contaminated sites. We compared common pure-phase Zn minerals with Zn-rich mine waste containing a complex mixtures of different phases. Studying pure phase $\mathrm{Zn}$ minerals allows us to directly evaluate the effect of mineralogy on bioavailability and bioaccessibility, and other factors that may affect metal mobility such as organic matter, iron oxides, and cation exchange capacity.

\section{Materials and methods}

\subsection{Particle characterization}

We obtained samples of smithsonite $\left[\mathrm{ZnCO}_{3}\right]$, hydrozincite $\left[\mathrm{Zn}_{5}\left(\mathrm{CO}_{3}\right)_{2}(\mathrm{OH})_{6}\right]$, hemimorphite $\left[\mathrm{Zn}_{4} \mathrm{Si}_{2} \mathrm{O}_{7}(\mathrm{OH})_{2} \cdot \mathrm{H}_{2} \mathrm{O}\right]$, sphalerite $[(\mathrm{Zn}, \mathrm{Fe}) \mathrm{S}]$ and zincite $[(\mathrm{Zn}, \mathrm{Mn}) \mathrm{O}]($ Table 1) from the Harvard University Mineralogical Museum (Cambridge, MA). Samples were ground with a mortar and pestle and then sieved through a $38-\mu \mathrm{m}$ pore-sized brass sieve with stainless steel wire. In addition, a sample of weathered mine waste collected from a pile at the Tar Creek Superfund Site (Oklahoma, U.S.A.) was air-dried at room temperature and sieved to $<38 \mu \mathrm{m}$ without grinding. This site was a former $\mathrm{Pb}$ and $\mathrm{Zn}$ mine where the major ores produced were sphalerite and galena (PbS) (McKnight and Fischer, 1970). The high Zn concentrations (up to $22 \% \mathrm{Zn}$ by mass in $<1 \mu \mathrm{m}$ particles) in mine waste (Schaider et al., 2007) raise concerns about elevated $\mathrm{Zn}$ exposures for residents. Previous analyses of the <38 $\mu \mathrm{m}$ mine waste samples using X-ray diffraction showed that $20-35 \%$ of $\mathrm{Zn}$ was present as hemimorphite and sphalerite and the majority in poorly crystalline secondary mineral forms (Schaider et al., 2007). These particles are small enough to be transported by wind (Duggan et al., 1985) and deposited in the nose and oral pharynx (Brain and Valberg, 1979).

All samples were divided into three aliquots. One was analyzed for specific surface area (SSA) by the Brunauer-Emmett-Teller (BET) method of $\mathrm{N}_{2}$ adsorption at the National Institute for Occupational Safety and Health (Morgantown, WV) (Brunauer et al., 1938). The second set of aliquots was analyzed for size, morphology and elemental composition. 
Aqueous suspensions of particles were analyzed for size distribution in a Beckman-Coulter LS 13320 Laser Diffraction Particle Size Analyzer (LDPSA) (Beckman Coulter, Inc., Brea, CA). Similar suspensions of particles were spread onto carbon adhesive tabs on aluminum scanning electron microscopy (SEM) specimen mount stubs (Electron Microscopy Sciences, PA). After drying under vacuum, morphology and elemental composition were assessed using a Leo $1450 \mathrm{VP}$ scanning electron microscope with energy-dispersive X-ray spectroscopy (SEM-EDX) at $15 \mathrm{kV}$ (Carl Zeiss SMT, Inc., Thornwood, NY). Dry samples of minerals were also analyzed with X-ray diffraction for phase verification.

The third set of aliquots was neutron-activated at the MIT Nuclear Reactor Laboratory (Cambridge, MA) with a thermal neutron flux of $5 \times 10^{13} \mathrm{n} / \mathrm{cm}^{2}$ s for 120 hours (mine waste) or 6 hours (pure-phase $\mathrm{Zn}$ minerals). Longer neutron activation of mine waste was necessary because the $\mathrm{Zn}$ concentration was lower. Neutron irradiation generated ${ }^{65} \mathrm{Zn}$, which decays with a half-life of 244.3 days and emits gamma energies of 345, 770 and 1115 $\mathrm{keV}$. These radioactive particles were used in in vitro extractions and geochemically-based extractions and in pharmacokinetic studies in rats. Specific activities for ${ }^{65} \mathrm{Zn}$ in each particle are listed in Table 1 and reflect their respective $\mathrm{Zn}$ concentration. Major and trace elemental composition of the mine waste was determined with instrumental neutron activation analysis.

\subsection{In vitro extraction tests}

We used a range of $\mathrm{pH}$ and chemical conditions to measure in vitro bioaccessibility. Simulated gastric fluid extraction was performed in a $\mathrm{pH} 1.5$ fluid $\left(1 \mathrm{hour}, 37^{\circ} \mathrm{C}\right)(\mathrm{OSWER}$, 2007). A pH 4.5 weak salt solution $\left(5\right.$ days, $\left.37^{\circ} \mathrm{C}\right)$ was used to simulate some biological environments such as phagolysosomal fluid in phagocytic cells (Stefaniak et al., 2005). A $\mathrm{pH} 7.4$ solution ( 1 hour, $37^{\circ} \mathrm{C}$ ) was used to simulate the conditions in the nasal epithelium and oropharynx. All extractions were performed with constant mixing using an Adams nutator Model 1105 (Clay Adams, Parsippany, NJ) at $12 \mathrm{rpm}$. Extraction solutions were filtered through a $0.2 \mu \mathrm{m}$ syringe tip filter to remove particle-bound ${ }^{65} \mathrm{Zn}$. Since some particles may be smaller than $0.2 \mu \mathrm{m}$, the filtrate was then centrifuged at $317,000 \mathrm{xg}$ and the supernatant was carefully removed. This extra step reduced the probability of measuring ${ }^{65} \mathrm{Zn}$ in very small particles that may pass through the filter. For each extraction, bioaccessibility was calculated as the percent of total ${ }^{65} \mathrm{Zn}$ that was dissolved and present in the filtered and ultracentrifuged solution.

Simulated gastric fluid extractions followed a protocol developed by the U.S. Environmental Protection Agency (USEPA) for $\mathrm{Pb}$ and validated with in vivo results (OSWER, 2007). The solid:liquid ratio was modified to $1: 1000$. While the method recommends a solid:liquid ratio of 1:100, it also notes the potential for precipitation of dissolved metal when extractions are performed on solid phases with concentrations above 50,000 ppm (OSWER, 2004, 2007). The pure phase $\mathrm{Zn}$ minerals used in this study had $52-73 \% \mathrm{Zn}$ by mass. To maintain the same limit on $\mathrm{Zn}$ concentration in solution implies that a solid:liquid ratio of 1:1000 is appropriate. Although $\mathrm{Zn}$ is more soluble than $\mathrm{Pb}$ (used for validation), a similar limit on metal concentration in solution was selected to minimize potential precipitation of other secondary mineral phases.

\subsection{Geochemically-based sequential extractions}

Geochemically-based sequential extractions were performed on the six particle samples. This protocol uses a series of increasingly stringent solutions selected to extract metals in 5 operationally defined phases: (I) ion-exchangeable ( $1 \mathrm{M} \mathrm{MgCl}_{2}, \mathrm{pH} 7,1 \mathrm{~h}$ ); (II) carbonate (1

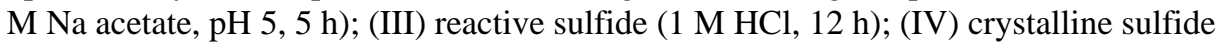
(concentrated $\mathrm{HNO}_{3}, 2 \mathrm{~h}$ ); and (V) residual (remainder after previous extraction steps). The 
protocol was adapted from published methods (Bostick et al., 2001; Huerta-Diaz and Morse, 1992; Keon et al., 2001; Tessier et al., 1979). The solid:liquid ratio was similarly modified to 1:1000.The first two steps encompass parameters that may realistically be found under environmental conditions. Thus, the sum of metals extracted in these two steps can be considered geoavailable.

\subsection{In vivo bioavailability studies}

The protocols were approved by the Harvard Medical Area Animal Care and Use Committee. Weanling Sprague-Dawley male rats were obtained from Taconic Farms (Germantown, NY) and housed at the Harvard Center for Comparative Medicine. They had access to commercial chow (PicoLab Rodent Diet 5053, Framingham, MA) and water ad libitum. All animals were acclimatized to our facilities for a week before starting the experiments. Neutron-activated mine waste and $\mathrm{Zn}$ mineral particles were suspended in phosphate-buffered saline solution (PBS) at $25 \mathrm{mg} / \mathrm{ml}$ for intranasal (IN) $(0.2 \mathrm{ml} / \mathrm{kg}$ body weight) or at $3.33 \mathrm{mg} / \mathrm{ml}$ for gavage administration $(1.5 \mathrm{ml} / \mathrm{kg})$. Particles in suspension were dispersed using a bath sonicator for five minutes before dosing. Aliquots of each suspension were measured in a Packard gamma counter (Cobra Quantum, Packard Instrument, Downers Grove, IL), and specific activities were calculated (Table 1). The particle dose was $5 \mathrm{mg} / \mathrm{kg}$ for both routes of administration. Based on particle $\mathrm{Zn}$ concentrations, the estimated $\mathrm{Zn}$ dose ranged from 0.5 to $3.65 \mathrm{mg} / \mathrm{kg}$ body weight. Soluble ${ }^{65} \mathrm{ZnCl}_{2}$ (specific activity $=2.39 \mathrm{mCi} /$ $\mathrm{mg}$ ) was obtained from Perkin Elmer (Billerica, MA) and administered at the same volume doses and at a dose of $0.006 \mathrm{mg} \mathrm{Zn} / \mathrm{kg}$ and $16.1 \mu \mathrm{Ci}{ }^{65} \mathrm{Zn} / \mathrm{kg}$ body weight.

Before IN instillation or gavage, rats were anesthetized with isoflurane (Halocarbons Lab, Inc., North Augusta, SC). The particle suspension or soluble ${ }^{65} \mathrm{ZnCl}_{2}$ was instilled into the nasal cavity. Gavage administration was performed in similarly anesthetized rats, placed on a slanted board where they were supported by an elastic band under the upper incisors. Each dose was instilled into the stomach using a gavage needle inserted transorally through the esophagus to the stomach. All rats (six per group) were dosed twice weekly for three weeks to simulate continuous exposure likely to occur in exposed populations. Rats were sacrificed and tissue ${ }^{65} \mathrm{Zn}$ levels were analyzed four days after the last dosing. The whole brain, spleen, kidneys, heart, , liver, lungs, GI tract, testes and multiple samples of blood, bone marrow, skeletal muscle, and skin were collected, weighed, and analyzed in a gamma counter. We did not collect and analyze urine and feces and so the amount of ${ }^{65} \mathrm{Zn}$ that was first absorbed and then excreted cannot be estimated. Absolute bioavailability (ABA) was calculated as the percentage of the total ${ }^{65} \mathrm{Zn}$ dose retained in each organ. The sum of all analyzed organs and tissues was considered as the total ABA. Relative bioavailability (RBA) was calculated as $\mathrm{ABA}$ of each particle sample relative to ${ }^{65} \mathrm{ZnCl}_{2}$.

\subsection{Statistical analyses}

Differences in the ${ }^{65} \mathrm{Zn}$ tissue distribution among the particles were analyzed using multivariate analysis of variance (MANOVA) with Bonferroni (Dunn) post hoc tests using SAS Statistical Analysis software (SAS Institute, Cary, NC). In vitro extraction assays, sequential extractions and particle characteristics were tested as predictors of ABA with multivariate linear regression analyses using Stata/SE statistical software (StataCorp LP, College Station, TX). Bioaccessibility, sequential extraction and bioavailability data were logit transformed to meet assumptions of normality.

\section{Results and discussion}

We compared in vitro extractions and geochemically-based extractions with in vivo bioavailability of $\mathrm{Zn}$ in five pure-phase $\mathrm{Zn}$ minerals and a $\mathrm{Zn}$-rich mine waste in rats. We 
also examined the influence of particle characteristics on bioavailability. By measuring $\mathrm{Zn}$ dissolution from radioactive neutron-activated particles, we utilized a highly sensitive method that measured only ${ }^{65} \mathrm{Zn}$ released from the particles and excluded background $\mathrm{Zn}$ from dietary sources. The sensitivity of ${ }^{65} \mathrm{Zn}$ detection also avoided the use of high $\mathrm{Zn}$ doses that may alter $\mathrm{Zn}$ homeostasis or saturate $\mathrm{Zn}$ transport mechanisms.

\subsection{Particle morphology and elemental composition}

Particles were examined by SEM (Figure 1), which revealed differences in size, shape and morphology. The micrographs showed a high degree of heterogeneity in shapes and particle sizes within and among samples. Elemental mapping using SEM-EDX in randomly selected micrographs showed that $\mathrm{Zn}$ was uniformly distributed in these minerals, regardless of size and shape. By comparison, mine waste particles had more heterogeneous elemental distributions (data not shown). Approximately $35 \%$ of randomly selected mine waste particles contained no detectable $\mathrm{Zn}$. Elements associated with host rock minerals (chert, dolomite) or other metal sulfides $\left(\mathrm{FeS}_{2}, \mathrm{PbS}\right)$ were also detected, including calcium, magnesium, silicon, arsenic, lead, iron, aluminum, and sulfur. Other metals were also detected in the $\mathrm{Zn}$ mineral particles. Zincite contained manganese, which typically co-occurs with $\mathrm{Zn}$ in this mineral. Smithsonite contained some silicon, calcium and cadmium. XRD analyses showed that hydrozincite hemimorphite, sphalerite, and zincite samples were pure while smithsonite contained $13.1 \%$ quartz. Previous XRD analyses of the $<38 \mu \mathrm{m}$ mine waste samples showed that $20-35 \%$ of $\mathrm{Zn}$ was present as hemimorphite and sphalerite and the majority in poorly crystalline secondary mineral forms (Schaider et al., 2007).

\subsection{Surface area and size distribution}

Higher surface area of particles increases their dissolution rates (Kreyling et al., 1990) and thus metal bioavailability. Our BET analyses showed that specific surface areas (SSA) varied significantly (Table 1), with hydrozincite having 10 to 100 times greater SSA than the other samples. Based on LDPSA analyses of particle size distributions (Table 1), mine waste had the smallest geometric mean diameter while hemimorphite had the largest. Although hydrozincite had the largest SSA according to BET analyses, its mean and mode particle diameters were among the largest, suggesting that particle diameter, as measured by LDPSA, does not necessarily reflect available surface area. As seen in Figure 1F, variable particle shapes may account for these discrepancies.

\subsection{In vitro bioaccessibility tests}

Zn bioaccessibility varied widely depending on the mineral form and extraction conditions (Table 2). Low $\mathrm{Zn}$ bioaccessibility was observed at $\mathrm{pH} 7.4 ; \unlhd) .1 \%$ of ${ }^{65} \mathrm{Zn}$ was dissolved from smithsonite, hydrozincite, zincite, and sphalerite and $<1 \%$ of ${ }^{65} \mathrm{Zn}$ was dissolved from hemimorphite and mine waste. At pH 4.5, mine waste showed the highest bioaccessibility, with $92 \%{ }^{65} \mathrm{Zn}$ dissolved into the extraction fluid. Smithsonite, hemimorphite, zincite and hydrozincite showed moderate bioaccessibility (35-57\%) and sphalerite showed minimal bioaccessibility $(1.1 \%)$. $\mathrm{Zn}$ bioaccessibility was consistently higher at $\mathrm{pH} 1.5$ than at $\mathrm{pH} 4.5$ or 7.4. Bioaccessibility at $\mathrm{pH} 1.5$ was $98 \%$ for mine waste, and $96-97 \%$ for hemimorphite, zincite, and hydrozincite. Smithsonite showed slightly lower bioaccessibility (72\%), and sphalerite again showed minimal bioaccessibility $(1.7 \%)$.

Enhanced Zn bioaccessibility under more acidic conditions is consistent with previous studies showing increased $\mathrm{Zn}$ mobility in soils at lower pH (Sauvé et al., 2000) and increased bioaccessibility of As, Cd and Pb. Juhasz et al. (2009b) compared As bioaccessibility in contaminated soils using four in vitro gastric fluid extraction solutions $(\mathrm{pH} 1.5-2.5)$ and four in vitro intestinal extractions (pH 5.5-7.5). Similarly, $\mathrm{Cd}$ bioaccessibility was higher in gastric fluid extractions than in intestinal fluid extractions, and 
among gastric fluid extractions, the $\mathrm{pH} 1.5$ solution (same composition as in our study) generally showed the highest bioaccessibility 1.5 (Juhasz et al., 2010). Arsenic bioaccessibility was generally higher in gastric extractions than in intestinal extractions, although the differences were less pronounced (Juhasz et al., 2009a).

\subsection{Geochemically-based sequential extractions}

Mine waste, hemimorphite, zincite and hydrozincite contained $\mathrm{Zn}$ in relatively labile phases (Table 3). In these samples, $81-89 \%$ of ${ }^{65} \mathrm{Zn}$ was present in extraction stage I and II, representing geoavailable $\mathrm{Zn}$. The majority of remaining $\mathrm{Zn}(10-16 \%)$ was present in stage $\mathrm{V}$ (residual fraction), with $\_$$\%$ present in stages III and IV. Consistent with in vitro extraction results, sphalerite was the least labile mineral, with $>90 \%$ of ${ }^{65} \mathrm{Zn}$ extracted in stages IV and V. Surprisingly, only $28 \%$ of ${ }^{65} \mathrm{Zn}$ in smithsonite was dissolved in stage II, with $57 \%$ of ${ }^{65} \mathrm{Zn}$ in the stage III fraction. This may be due to presence of recalcitrant $\mathrm{Si}$ and Al-containing mineral impurities as well as kinetic constraints that may have led to low dissolution of the carbonate mineral during the extraction period. In addition, for each type of mineral, there may be a range of bioaccessibility depending on the properties of each specific mineral sample. Results from geochemically-based sequential extractions should be viewed as a guide since there are inherent limitations to sequential extractions, such as lack of specificity and the potential sorption or re-precipitation of solubilized metals back onto the solid sample surface (Kheboian and Bauer, 1987; Ostergren et al., 1999).

\subsection{In vivo bioavailability of $\mathrm{Zn}$ after intranasal and gavage administration in rats}

Absolute bioavailability results (Tables 4 and 5) showed that the overall organ distributions for both IN and gavage administration were statistically different among particles and compared to ${ }^{65} \mathrm{ZnCl}_{2}$ (MANOVA, $\mathrm{P}<0.05$ ). We considered the total percentage of ${ }^{65} \mathrm{Zn}$ dose in blood and all tissues examined as total ABA, an indicator of its retention in the body. In general, total ABA after IN administration decreased in the following order: mine waste $>{ }^{65} \mathrm{ZnCl}_{2}>$ hydrozincite $>$ hemimorphite $>$ zincite $>$ smithsonite $>$ sphalerite (Table 4). Interestingly, $\mathrm{Zn} \mathrm{ABA}$ was higher for mine waste than dissolved ${ }^{65} \mathrm{ZnCl}_{2}$. We hypothesize that $\mathrm{Zn}$ ions from $\mathrm{ZnCl}_{2}$ may quickly form conjugates with proteins in nasal or gastrointestinal mucosa that attenuate their absorption, whereas interactions with $\mathrm{Zn}$ from particles may be different due to slow dissolution. The highest amounts of ${ }^{65} \mathrm{Zn}$ were found in the skeletal muscle and liver, mainly due to their large weights. The 5 tissues and organs with highest concentrations of ${ }^{65} \mathrm{Zn}$ were hair, nails, teeth, bone marrow, and liver (data not shown). The low levels of ${ }^{65} \mathrm{Zn}$ in the lungs confirmed that very few IN administered particles were aspirated into the lungs. Therefore, ${ }^{65} \mathrm{Zn}$ in peripheral tissues primarily reflects absorption through the nasal or intestinal epithelium.

A similar distribution of ${ }^{65} \mathrm{Zn}$ among tissues was observed after gavage administration (Table 5). Significant differences among the particles in $\mathrm{Zn}$ total ABA were observed in the same decreasing order measured after IN administration. This suggests that tissue uptake of ${ }^{65} \mathrm{Zn}$ after IN dosing likely resulted from swallowed particles. Overall, ABA for ${ }^{65} \mathrm{Zn}$ was 1.2 to 1.6 times higher following gavage compared to IN administration, suggesting greater $\mathrm{Zn}$ bioavailability from ingested particles compared to particles deposited in the nasal passage. These relative differences may be due to loss of a portion of the particles deposited in the nasal cavity before being swallowed. ABA post IN and gavage ranged from 0.6 to $13.7 \%$ depending on particle type and route of exposure. Estimates of ABA may be slightly underestimated due to the exclusion of urine (Johnson et al., 1988) and body clearance of Zn over the study period. Other factors such as phytic acids in the chow (Davies and Nightingale, 1975), iron and zinc status (Johnson et al., 1988; Miller et al., 1971), dietary proteins (Mahalko et al., 1983), and ingestion of other metals also influence absorption and excretion of $\mathrm{Zn}$ (Gooneratne et al., 2011). However, in our experiment, relative differences 
among particles are most likely due to the mineralogy and morphology of the particles themselves, since these other factors did not vary in our experiment.

Few studies have compared bioaccessibility and bioavailability of $\mathrm{Zn}$ in animals. $\mathrm{Zn}$ bioavailability from different grades of $\mathrm{ZnO}$, and $\mathrm{Zn}$ metals relative to $\mathrm{ZnSO}_{4}$, were significantly different confirming that chemical forms of $\mathrm{Zn}$ influence bioavailability (Edwards and Baker, 1999). Another study compared $\mathrm{Zn}$ and Cu bioaccessibility with bioavailability in lugworms (Arenicola marina) from contaminated marine sediments and found that $\mathrm{Zn}$ bioaccessibility in fluids containing serum albumin (a surrogate for the gut fluids of sediment feeders) did not correlate with bioaccumulation (Turner et al., 2008). Low Zn bioavailability from inhaled zinc-cadmium sulfide was reported in rats (Bergmann et al., 2000). Although previous studies have shown that $\mathrm{Zn}$ speciation influences bioaccessibility and bioavailability, our study also compares these parameters across a broader range of chemical forms as well as routes of exposure.

\subsection{Correlation of mineralogy and particle characteristics with bioavailability and bioaccessibility}

Our results show that mineralogy influences bioavailability and bioaccessibility of $\mathrm{Zn}$. Mine waste particles had the highest bioavailability and bioaccessibility at $\mathrm{pH} 1.5$ and 4.5 , consistent with our previous findings that the surface of these particles contained $\mathrm{Zn}$ in secondary minerals that are poorly crystalline and relatively bioaccessible (Schaider et al., 2007). Mine waste from the Tar Creek site has undergone weathering for at least 35 years. Simulated aging of contaminated soil using EDTA leaching has been shown to increase $\mathrm{Pb}$ and decrease $\mathrm{Cd}$ mobility and bioaccessibility, as determined by in vitro extractions, whereas Zn bioaccessibility was not affected (Udovic and Lestan, 2009). Zn bioavailability and bioaccessibility in sulfide form (sphalerite) were lowest, consistent with previous studies (Bergmann et al., 2000; Klimisch, 1993). Surprisingly, zinc carbonate (smithsonite) yielded lower bioavailability than hemimorphite. As noted in Section 3.4, a range of factors may have limited the dissolution of smithsonite.

Other studies have shown that particle surface area influences bioavailability. We found that SSA alone was not correlated with Zn ABA, although to some extent, particles with higher SSA tended to have greater bioavailability. The highest SSA was measured for hydrozincite $\left(93.4 \mathrm{~m}^{2} / \mathrm{g}\right)$, which may have contributed to the relatively high tissue concentrations of $\mathrm{Zn}$ after both IN and gavage administration of hydrozincite. This is followed by hemimorphite $\left(3.9 \mathrm{~m}^{2} / \mathrm{g}\right)$ and smithsonite $\left(2.7 \mathrm{~m}^{2} / \mathrm{g}\right)$, particles with similar SSA and corresponding ABA. Lower tissue ${ }^{65} \mathrm{Zn}$ from zincite and sphalerite corresponded with their lower SSA. However, mine waste had higher Zn bioavailability than hydrozincite despite having 10 times lower SSA. Smithsonite and zincite showed similar Zn ABA, although smithsonite had 3 times higher SSA. Although influenced by SSA, our results demonstrated that the mineralogical form is a major determinant of Zn bioavailability.

\subsection{Regression analyses of zinc in vitro bioaccessibility, in vivo bioavailability, and geoavailability}

While in vitro tests have been developed for assessing bioaccessibility in a risk assessment context, geochemists have used sequential extractions as one method to assess metal lability and to characterize the speciation of metals in solid phases (Tessier et al., 1979). Depending on the extraction solutions used, sequential extractions may provide a measure of geoavailability. Thus, we conducted regression analyses to examine whether in vitro measures of zinc bioaccessibility were correlated with geoavailability as measured by sequential extractions and with in vivo bioavailability, and whether geoavailability was correlated with in vivo bioavailability (Table 6). 
A significant relationship was observed between bioavailability and in vitro bioaccessibility. In vivo bioavailability post-IN installation was significantly correlated with bioaccessibility at $\mathrm{pH} 4.5\left(\mathrm{R}^{2}=0.86, \mathrm{p}=0.005\right)$ and at $\mathrm{pH} 1.5\left(\mathrm{R}^{2}=0.79, \mathrm{p}=0.01\right)$. In vivo bioavailability postgavage was significantly correlated with bioaccessibility at $\mathrm{pH} 4.5\left(\mathrm{R}^{2}=0.83, \mathrm{p}=0.008\right)$ and at $\mathrm{pH} 1.5\left(\mathrm{R}^{2}=0.72, \mathrm{p}=0.02\right)$. Finally, correlation coefficients between bioavailability postIN and post-gavage with geoavailability were $0.67(\mathrm{p}=0.03)$ and $0.60(\mathrm{p}=0.04)$, respectively. Both in vitro bioaccessibility tests appeared to overpredict absolute bioavailability estimated as the total retained dose. One reason for this apparent overprediction is that part of the bioavailable $\mathrm{Zn}$ absorbed by the animals was excreted over the course of three-week dosing experiment. When comparing in vitro bioaccessibility with IN absolute bioavailability, the slopes of the relationship were $\mathrm{y}=0.062 \mathrm{x}-0.0014(\mathrm{pH} 1.5)$ and $\mathrm{y}=0.114-0.0031(\mathrm{pH} 4.5)$. For gavage ABA, the slopes were $\mathrm{y}=0.083 \mathrm{x}-0.0003(\mathrm{pH} 1.5)$ and $\mathrm{y}=0.151 \mathrm{x}-0.002(\mathrm{pH}$ 4.5). Figure 2 shows correlation of bioaccessibility at $\mathrm{pH} 4.5$ on in vivo $\mathrm{RBA}$ of ${ }^{65} \mathrm{Zn}$ (relative to $\mathrm{ZnCl}_{2}$ ) post-gavage (Fig 2A) or post-IN instillation (Fig 2B). The strengths of the correlations are shown by the high $\mathrm{R}^{2}$. In both instances, variability in in vitro bioaccessibility accounted for $88 \%$ of the variability observed in in vivo bioavailability.

Zinc geoavailability (sequential extraction fractions I + II) was also correlated with bioaccessibility when particle size (mean diameter in LDPSA analyses) was included in the regression models ( $\mathrm{pH} 4.5, \mathrm{R}^{2}=0.98, \mathrm{p}=0.002$ and $\mathrm{pH} 1.5, \mathrm{R}^{2}=0.99, \mathrm{p}<0.0001$ ). The particle size term in the regression models had negative coefficients (Table 6), indicating that larger particles had lower bioaccessibility.

Thus, our data showed that in vitro bioaccessibility tests with simulated gastric fluid extraction or phagolysosomal environment correlate strongly with in vivo bioavailability of $\mathrm{Zn}$ from particles of different mineralogy either after being ingested or deposited into the nasal passages.

\section{Conclusions}

Our data show that in vivo bioavailability of $\mathrm{Zn}$ from pure-phase minerals and a complex mixture of Zn phases (mine waste) depends on the chemical form of Zn, particle size, and route of exposure. The trends observed in in vitro extractions and geochemically-based sequential extractions were consistent with the in vivo results. The significance of these correlations confirms that solid phase speciation and geochemical alteration of speciation during weathering can have significant impacts on the biological uptake of zinc. Our study shows that in vitro tests can predict relative bioavailability of micronutrient metals such as $\mathrm{Zn}$ and can be useful in exposure assessment and for determining the efficacy of remediation strategies.

\section{Acknowledgments}

This study was funded by the National Institute of Environmental Health Sciences [P01 ES012874, ES000002] and by the US Environmental Protection Agency [RD-83172501]. We thank Carl Francis of the Harvard University Mineralogical Museum for zinc minerals, Jim Besancon, Britt Argow, Rebecca Stearns, Thomas Bork, Lin-Wen Hu and Deborah Sbarra for technical assistance and Brent Coull for help with statistical analyses.

\section{References}

Amidon GL, Lennernas H, Shah VP, Crison JR. A theoretical basis for a biopharmaceutic drug classification: the correlation of in vitro drug product dissolution and in vivo bioavailability. Pharmaceutical Research. 1995; 12:413-420. [PubMed: 7617530]

ATSDR. Priority List of Hazardous Substances. Agency for Toxic Substances and Disease Registry; Atlanta, GA: 2012. http://www.atsdr.cdc.gov/SPL/index.html 
Au C, Benedetto A, Aschner M. Manganese transport in eukaryotes: the role of DMT1. Neurotoxicology. 2008; 29:569-576. [PubMed: 18565586]

Bergmann JD, Metker LW, McCain WC, Beall PA, Michie MW, Lee RB. Intratracheal instillation of zinc-cadmium sulfide (ZnCdS) in Fischer 344 rats. Inhalation Toxicology. 2000; 12:331-346. [PubMed: 10715632]

Bostick BC, Hansel CM, La Force MJ, Fendorf S. Seasonal fluctuations in zinc speciation within contaminated wetland. Environmental Science and Technology. 2001; 35:3823-3829. [PubMed: 11642439]

Bradham KD, Scheckel KG, Nelson CM, Seales PE, Lee GE, Hughes MF, Miller BW, Yeow A, Gilmore T, Serda SM, Harper S, Thomas DJ. Relative bioavailability and bioaccessibility and speciation of arsenic in contaminated soils. Environmental Health Perspectives. 2011; 119:16291634. [PubMed: 21749965]

Brain JD, Valberg PA. Deposition of aerosol in the respiratory tract. American Review of Respiratory Diseases. 1979; 120:1325-1373. [PubMed: 391112]

Brunauer S, Emmett PH, Teller E. Adsorption of gases in multimolecular layers. Journal of American Chemical Society. 1938; 60:309-319.

Casteel SW, Weis CP, Henningsen GM, Brattin WJ. Estimation of relative bioavailability of lead in soil and soil-like materials using young swine. Environmental Health Perspectives. 2006; 114:1162-1171. [PubMed: 16882520]

Davies NT, Nightingale R. The effects of phytate on intestinal absorption and secretion of zinc, and whole-body retention of $\mathrm{Zn}$, copper, iron and manganese in rats. British Journal of Nutrition. 1975; 34:243-258. [PubMed: 1174496]

Duggan MJ, Inskip MJ, Rundle SA, Moorcroft JS. Lead in playground dust and on the hands of schoolchildren. Science of the Total Environment. 1985; 44:65-79. [PubMed: 4023696]

Edwards HM 3rd, Baker DH. Bioavailability of zinc in several sources of zinc oxide, zinc sulfate, and zinc metal. Journal of Animal Science. 1999; 77:2730-2735. [PubMed: 10521034]

El Safty A, El Mahgoub K, Helal S, Abdel Maksoud N. Zinc toxicity among galvanization workers in the iron and steel industry. Annals of New York Academy of Science. 2008; 1140:256-262.

Fosmire GJ. Zinc toxicity. American Journal of Clinical Nutrition. 1990; 51:225-227. [PubMed: 2407097]

Gooneratne SR, Laarveld B, Pathirana KK, Christensen DA. Effects of dietary $\mathrm{Cu}$, Mo and S on urinary $\mathrm{Cu}$ and $\mathrm{Zn}$ excretion in Simmental and Angus cattle. Research in Veterinary Science. 2011; 91:e116-120. [PubMed: 21338998]

Heyder, J.; Svarten, MU. Basic principles of particle behavior in the human respiratory tract. In: Bisgaard, H.; O'Callaghan, C.; Smaldone, GC., editors. Drug Delivery to the Lungs. Lung Biology in Health and Disease. Marcel Dekker; New York: 2002. p. 21-45.

Huerta-Diaz MA, Morse JW. Pyritization of trace-metals in anoxic marine sediments. Geochimica et Cosmochimica Acta. 1992; 56:2681-2702.

Johnson PE, Hunt JR, Ralston NV. The effect of past and current dietary Zn intake on Zn absorption and endogenous excretion in the rat. Journal of Nutrition. 1988; 118:1205-1209. [PubMed: 3054020]

Juhasz AL, Weber J, Naidu R, Gancarz D, Rofe A, Todor D, Smith E. Determination of cadmium relative bioavailability in contaminated soils and its prediction using in vitro methodologies. Environmental Science and Technology. 2010; 44:5240-5247. [PubMed: 20527788]

Juhasz AL, Weber J, Smith E, Naidu R, Marschner B, Rees M, Rofe A, Kuchel T, Sansom L. Evaluation of SBRC-gastric and SBRC-intestinal methods for the prediction of in vivo relative lead bioavailability in contaminated soils. Environmental Science and Technology. 2009a; 43:4503-4509. [PubMed: 19603669]

Juhasz AL, Weber J, Smith E, Naidu R, Rees M, Rofe A, Kuchel T, Sansom L. Assessment of four commonly employed in vitro arsenic bioaccessibility assays for predicting in vivo relative arsenic bioavailability in contaminated soils. Environmental Science and Technology. 2009b; 43:94879494. [PubMed: 20000545]

Kelley, ME.; Brauning, SE.; Schoof, RA.; Ruby, MV. Assessing Oral Bioavailability of Metals in Soil. Battelle Press; Columbia, OH: 2002. 
Keon NE, Swartz CH, Brabander DJ, Harvey C, Hemond HF. Validation of an arsenic sequential extraction method for evaluating mobility in sediments. Environmental Science and Technology. 2001; 35:2778-2784. [PubMed: 11452609]

Kheboian C, Bauer CF. Accuracy of selective extraction procedures for metal speciation in model aquatic sediments. Analytical Chemistry. 1987; 59:1417-1423.

Klimisch HJ. Lung deposition, lung clearance and renal accumulation of inhaled cadmium chloride and cadmium-sulfide in rats. Toxicology. 1993; 84:103-124. [PubMed: 8266332]

Kobayashi N, Okamura H. Effects of heavy metals on sea urchin embryo development. Part 2. Interactive toxic effects of heavy metals in synthetic mine effluents. Chemosphere. 2005; 61:1198-1203. [PubMed: 16263390]

Kreyling WG, Godleski JJ, Kariya ST, Rose RM, Brain JD. In vitro dissolution of uniform cobalt oxide particles by human and canine alveolar macrophages. American Journal of Respiratory Cell and Molecular Biology. 1990; 2:413-422. [PubMed: 2340182]

Mahalko JR, Sandstead HH, Johnson LK, Milne DB. Effect of a moderate increase in dietary protein on the retention and excretion of $\mathrm{Ca}, \mathrm{Cu}, \mathrm{Fe}, \mathrm{Mg}, \mathrm{P}$, and $\mathrm{Zn}$ by adult males. American Journal of Clinical Nutrition. 1983; 37:8-14. [PubMed: 6849284]

McKnight, ET.; Fischer, RP. US Geological Survey, Professional Paper 588. Washington, DC: 1970. Geology and Ore Deposits of the Pitcher Field, Oklahoma and Kansas; p. 162

Miller WJ, Wells ES, Gentry RP, Neathery MW. Endogenous zinc excretion and 65 Zn metabolism in Holstein calves fed intermediate to high but nontoxic zinc levels in practical diets. Journal of Nutrition. 1971; 101:1673-1681. [PubMed: 5126263]

Milton A, Johnson M. Arsenic in the food chains of a revegetated metalliferous mine tailings pond. Chemosphere. 1999; 39:765-779. [PubMed: 10448555]

Navarro MC, Perez-Sirvent C, Martinez-Sanchez MJ, Vidal J, Marimon J. Lead, cadmium and arsenic bioavailability in the abandoned mine site of Cabezo Rajao (Murcia, SE Spain). Chemosphere. 2006; 63:484-489. [PubMed: 16213550]

Ostergren JD, Brown GE, Parks GA, Tingle TN. Quantitative speciation of lead in selected mine tailings from Leadville, CO. Environmental Science and Technology. 1999; 33:1627-1636.

OSWER. Office of Solid Waste and Emergency Response. E.P.A., U.S. Estimation of Relative Bioavailability of Lead in Soil and Soil-like Materials Using in vivo and in vitro Methods. Washington, D.C: 2004.

OSWER. E.P.A., U.S. Guidance for Evaluating the Bioavailability of Metals in Soils for Use in Human Health Risk Assessment. Washington, D.C: 2007.

Otten, JJ.; Hellwig, JP.; Meyers, LD. Dietary Reference Intakes. The National Academies Press; Washington, D.C: 2006. p. 541

Ruby MV. Bioavailability of soil-borne chemicals: abiotic assessment tools. Human and Ecological Risk Assessment. 2004; 10:647-656.

Ruby MV, Davis A, Schoof R, Eberle S, Sellstone CM. Estimation of lead and arsenic bioavailability using a physiologically based extraction test. Environmental Science and Technology. 1996; 30:422-430.

Sauvé S, Hendershot W, Allen HE. Solid-solution partitioning of metals in contaminated soils: Dependence on $\mathrm{pH}$, total metal burden, and organic matter. Environmental Science and Technology. 2000; 34:1125-1131.

Schaider LA, Senn DB, Brabander DJ, McCarthy KD, Shine JP. Characterization of zinc, lead, and cadmium in mine waste: implications for transport, exposure, and bioavailability. Environmental Science and Technology. 2007; 41:4164-4171. [PubMed: 17612206]

Schilderman PA, Moonen EJ, Kempkers P, Kleinjans JC. Bioavailability of soil-adsorbed cadmium in orally exposed male rats. Environmental Health Perspectives. 1997; 105:234-238. [PubMed: 9105799]

Schroder JL, Basta NT, Casteel SW, Evans TJ, Payton ME, Si J. Validation of the in vitro gastrointestinal (IVG) method to estimate relative bioavailable lead in contaminated soils. Journal of Environmental Quality. 2004; 33:513-521. [PubMed: 15074802] 
Smith, KS. Strategies to predict metal mobility in surficial mining environments. In: DeGraff, JV., editor. Understanding and responding to hazardous substances at mine sites in the Western United States: Geological Society of America Reviews in Engineering Geology. 2007. p. 25-45.

Stefaniak AB, Guilmette RA, Day GA, Hoover MD, Breysse PN, Scripsick RC. Characterization of phagolysosomal simulant fluid for study of beryllium aerosol particle dissolution. Toxicology in Vitro. 2005; 19:123-134. [PubMed: 15582363]

Tessier A, Campbell PGC, Bisson M. Sequential extraction procedure for the speciation of particulate trace-metals. Analytical Chemistry. 1979; 51:844-851.

Turner A, Singh N, Millard L. Bioaccessibility and bioavailability of $\mathrm{Cu}$ and $\mathrm{Zn}$ in sediment contaminated by antifouling paint residues. Environmental Science and Technology. 2008; 42:8740-8746. [PubMed: 19192791]

Udovic M, Lestan $\mathrm{D}$. $\mathrm{Pb}, \mathrm{Zn}$ and $\mathrm{Cd}$ mobility, availability and fractionation in aged soil remediated by EDTA leaching. Chemosphere. 2009; 74:1367-1373. [PubMed: 19110294] 


\section{Highlights}

- Zinc particle mineralogy influences bioaccessibility and bioavailability.

- Zn bioavailability via gavage was $1.2-1.6$ times higher than via intranasal route.

- Zn particle geoavailability correlates with bioaccessibility.

- In vitro bioaccessibility tests can predict in vivo $\mathrm{Zn}$ bioavailability

- Metal speciation and geochemical alterations can impact Zn bioavailability. 


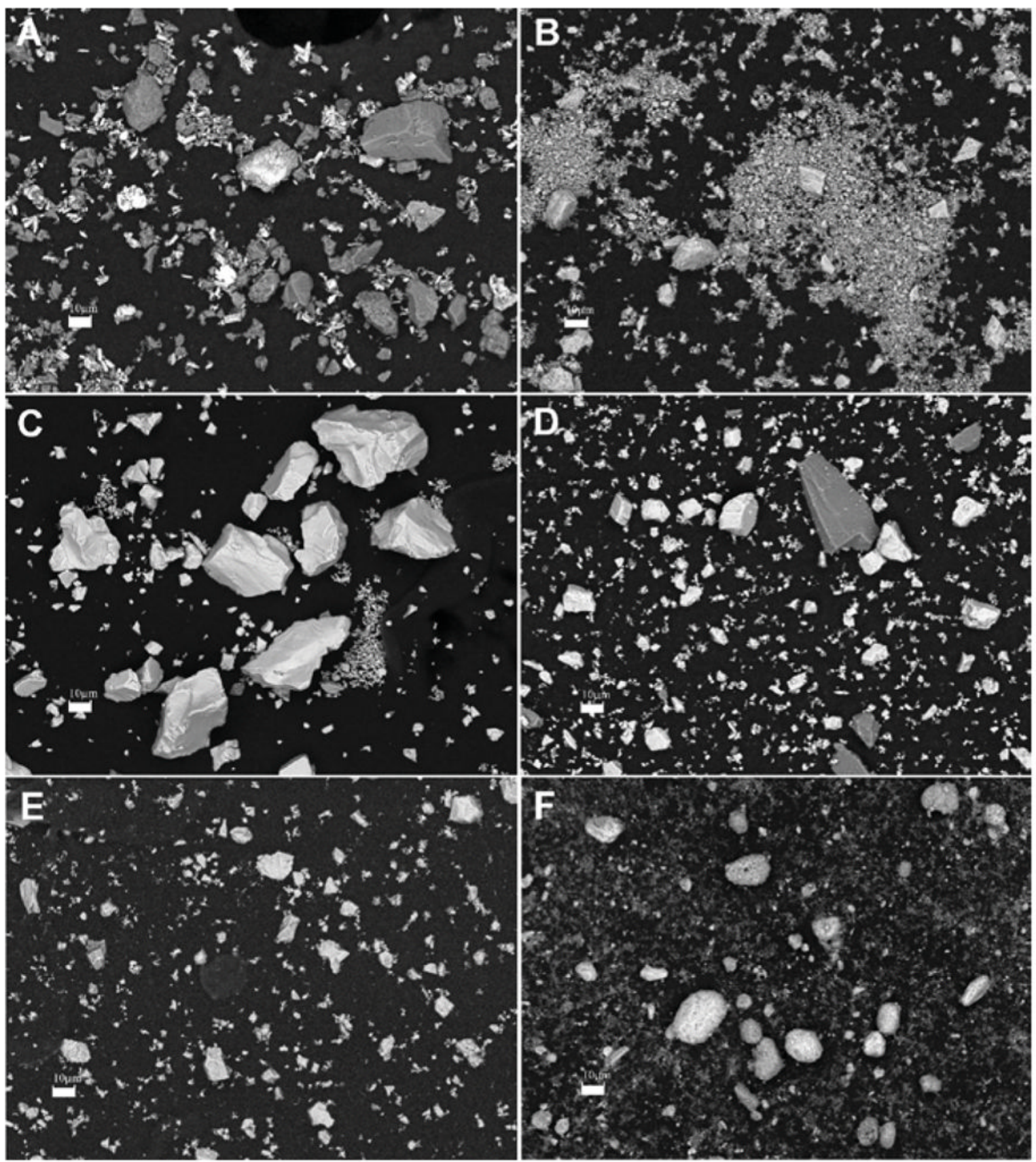

Figure 1.

Scanning electron micrographs of particles. Representative images from mine waste (A), hemimorphite (B), zincite (C), smithsonite (D), sphalerite (E) and hydrozincite (F) obtained using the backscatter mode. Micron bar $=10 \mu \mathrm{m}$. Brighter areas have higher average atomic number and indicate areas enriched in zinc and other metals. 

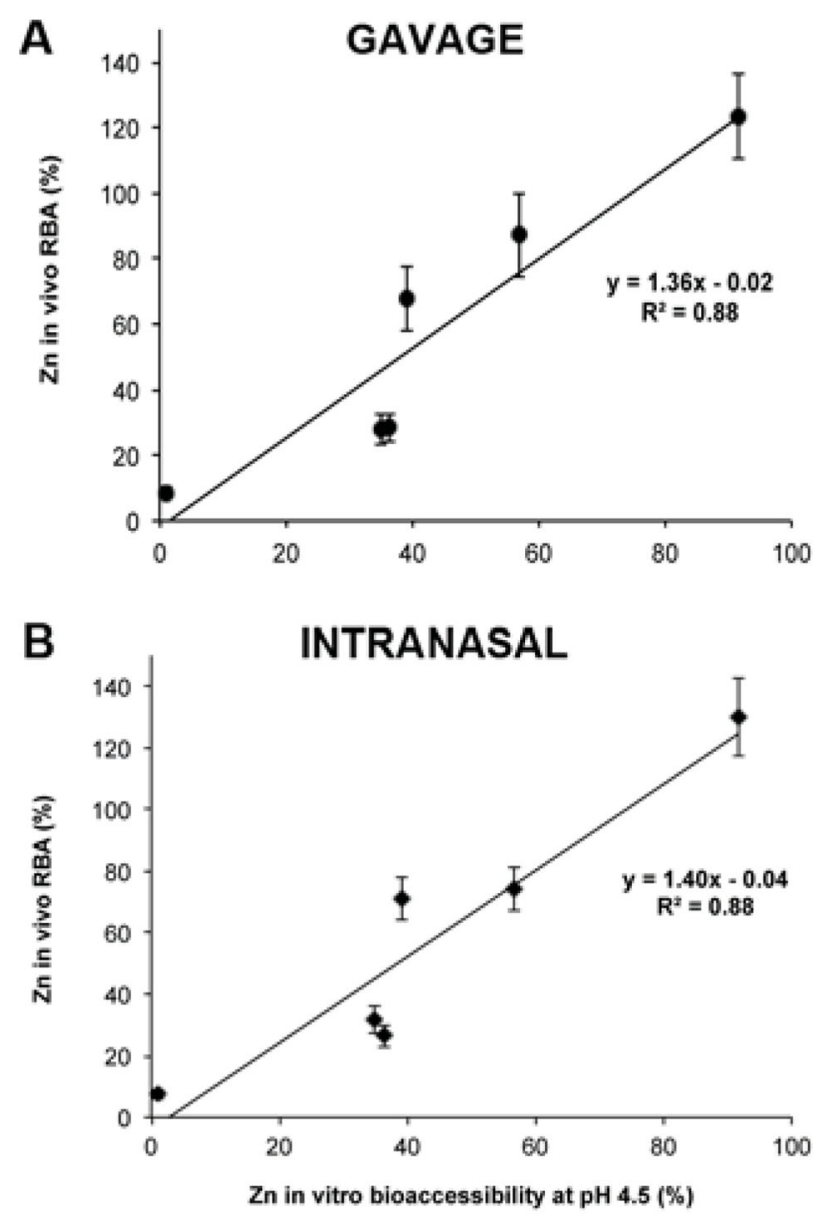

Figure 2.

Regression analysis of bioaccessibility at $\mathrm{pH} 4.5$ on in vivo $\mathrm{RBA}$ of ${ }^{65} \mathrm{Zn}$ (relative to $\mathrm{ZnCl}_{2}$ ) after IN (2A) or gavage (2B) administration. The in vitro extraction results significantly correlated with both post-intranasal $\left(\mathrm{r}^{2}=0.88\right)$ and post-gavage $\left(\mathrm{r}^{2}=0.88\right) \mathrm{Zn}$ relative in vivo bioavailability. $n=6$ rats per group. 


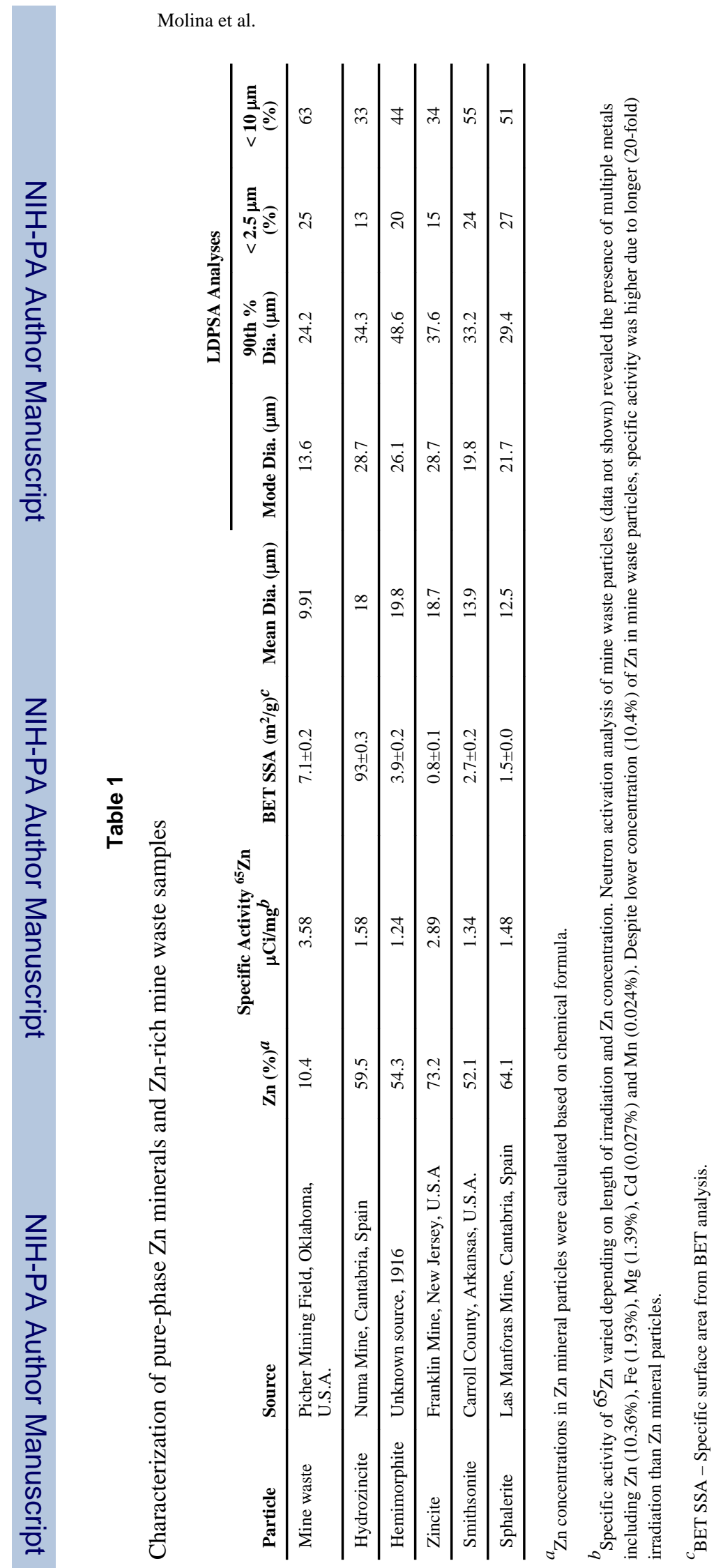

Environ Pollut. Author manuscript; available in PMC 2014 November 01. 


\section{Table 2}

Results of in vitro extraction tests. Results are presented as percentage of total ${ }^{65} \mathrm{Zn}$ measured in dissolved extraction solution after each specified time of incubation.

\begin{tabular}{lccc}
\hline & $\mathbf{p H ~ 7 . 4}^{\boldsymbol{a}}$ & $\mathbf{p H ~ 4 . 5}^{\boldsymbol{b}}$ & $\mathbf{p H ~ 1 . 5 ^ { c }}$ \\
& $\mathbf{1 ~ h}$ & $\mathbf{5 ~ d ~}$ & $\mathbf{1 ~ h ~}$ \\
Mine waste & 0.22 & 91.7 & $98.2 \pm 5.1$ \\
Hydrozincite & 0.09 & 56.8 & $97.4 \pm 3.7$ \\
Hemimorphite & 0.48 & 39.1 & $95.8 \pm 1.4$ \\
Zincite & 0.06 & 35.0 & $96.5 \pm 1.8$ \\
Smithsonite & 0.09 & 36.4 & $72.1 \pm 9.4$ \\
Sphalerite & 0.03 & 1.07 & $1.7 \pm 0.4$ \\
\hline
\end{tabular}

$a_{\mathrm{pH}}$ 7.4: $137 \mathrm{mM} \mathrm{NaCl}, 2.7 \mathrm{mM} \mathrm{KCl}, 8.1 \mathrm{mM} \mathrm{Na} 2 \mathrm{HPO}_{4} \cdot 2 \mathrm{H}_{2} \mathrm{O}, 1.76 \mathrm{mM} \mathrm{KH}_{2} \mathrm{PO}_{4}$

$b_{\mathrm{pH}} 4.5: 20 \mathrm{mM} \mathrm{KHC} 8 \mathrm{H}_{4} \mathrm{O}_{4}, 110 \mathrm{mM} \mathrm{NaCl}, 6.0 \mathrm{mM}$ glycine, $1.0 \mathrm{mM} \mathrm{Na} 2 \mathrm{HPO}_{4}, 0.5 \mathrm{mM} \mathrm{Na}_{2} \mathrm{SO}_{4}, 0.20 \mathrm{mM} \mathrm{CaCl} 2,50$ ppm benzalkonium chloride

${ }_{\mathrm{pH}}^{c}$ 1.5: 0.4 M glycine. Results expressed as mean $\pm \mathrm{SE}(\mathrm{n}=2)$. 


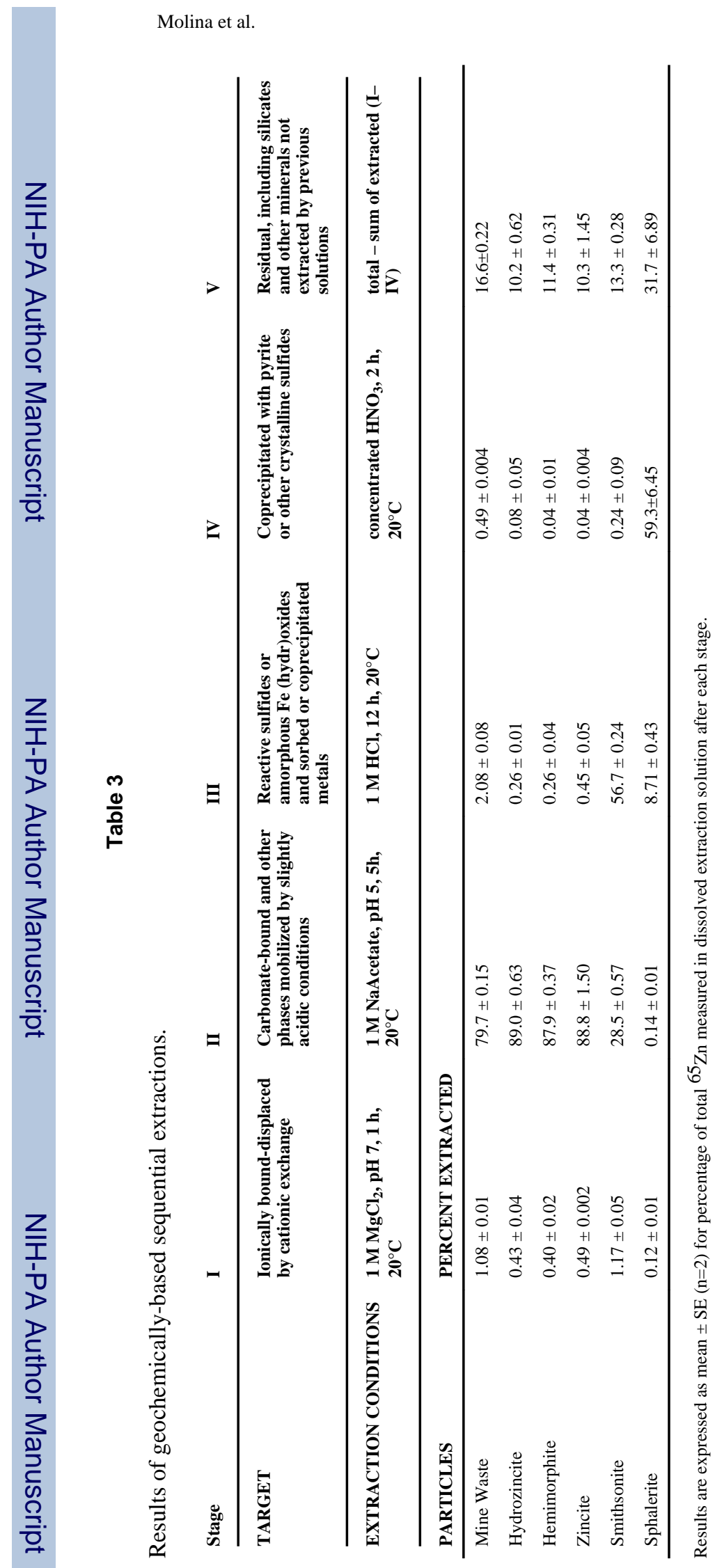

Page 18 


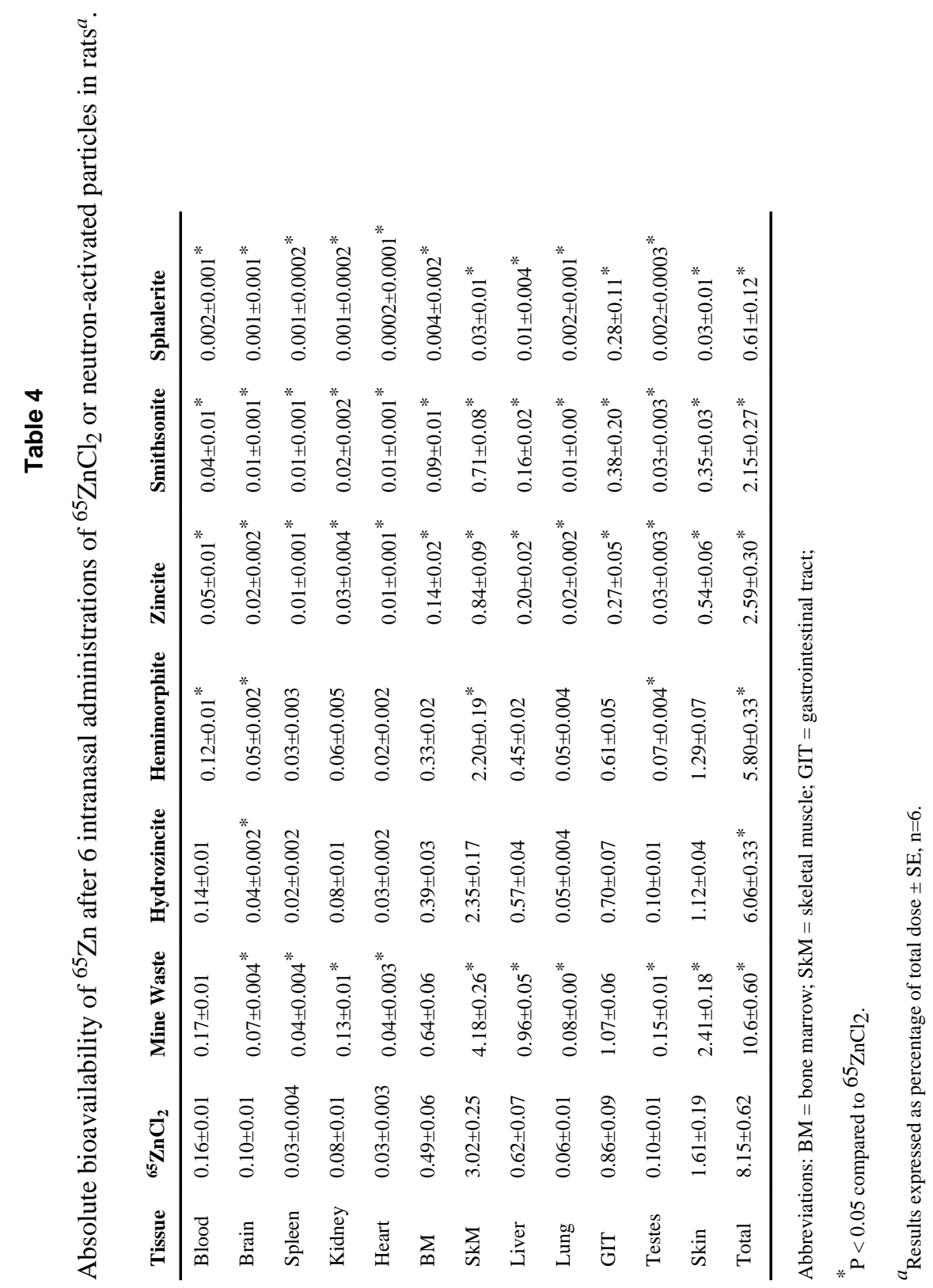




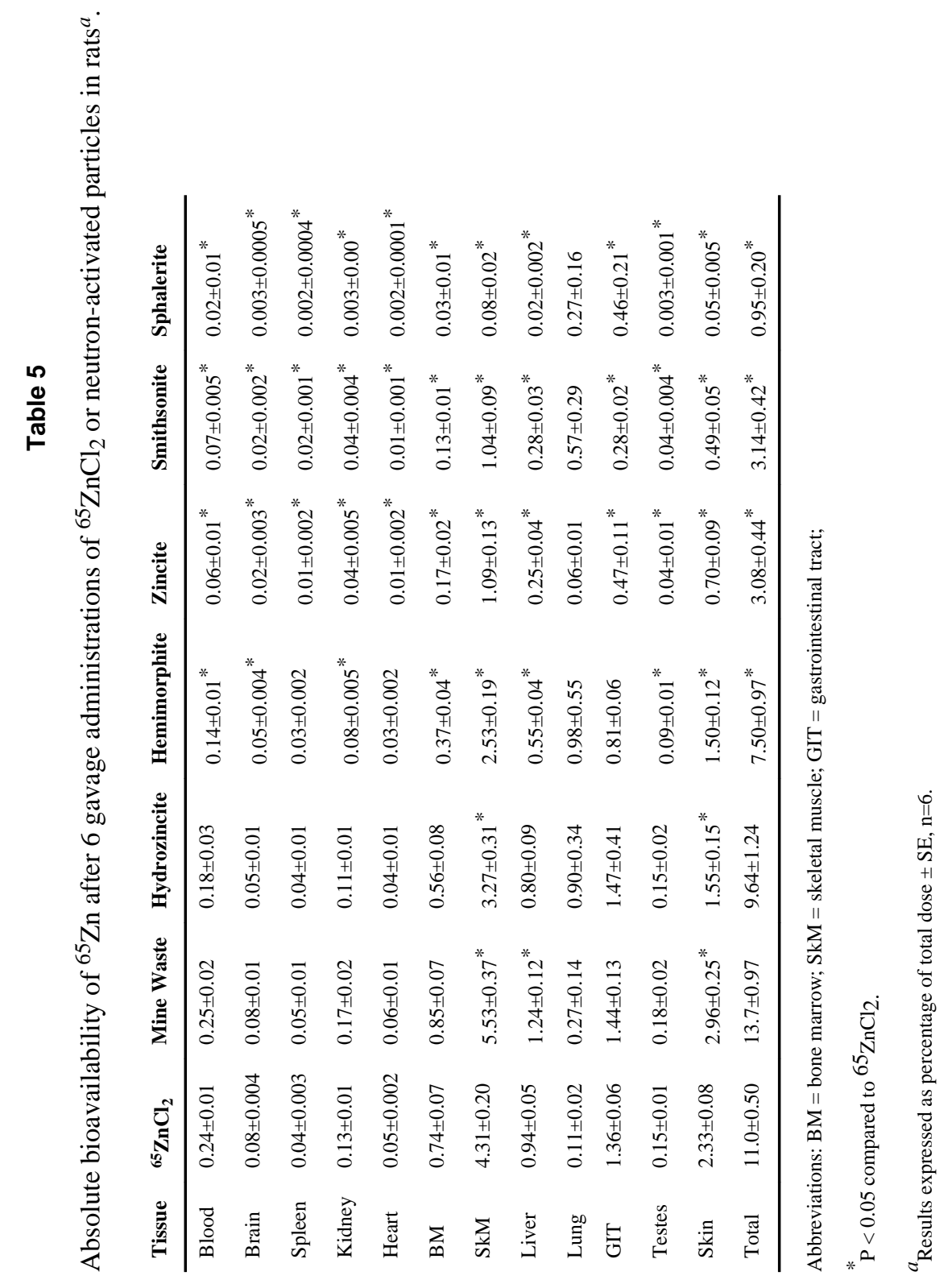




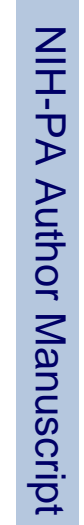

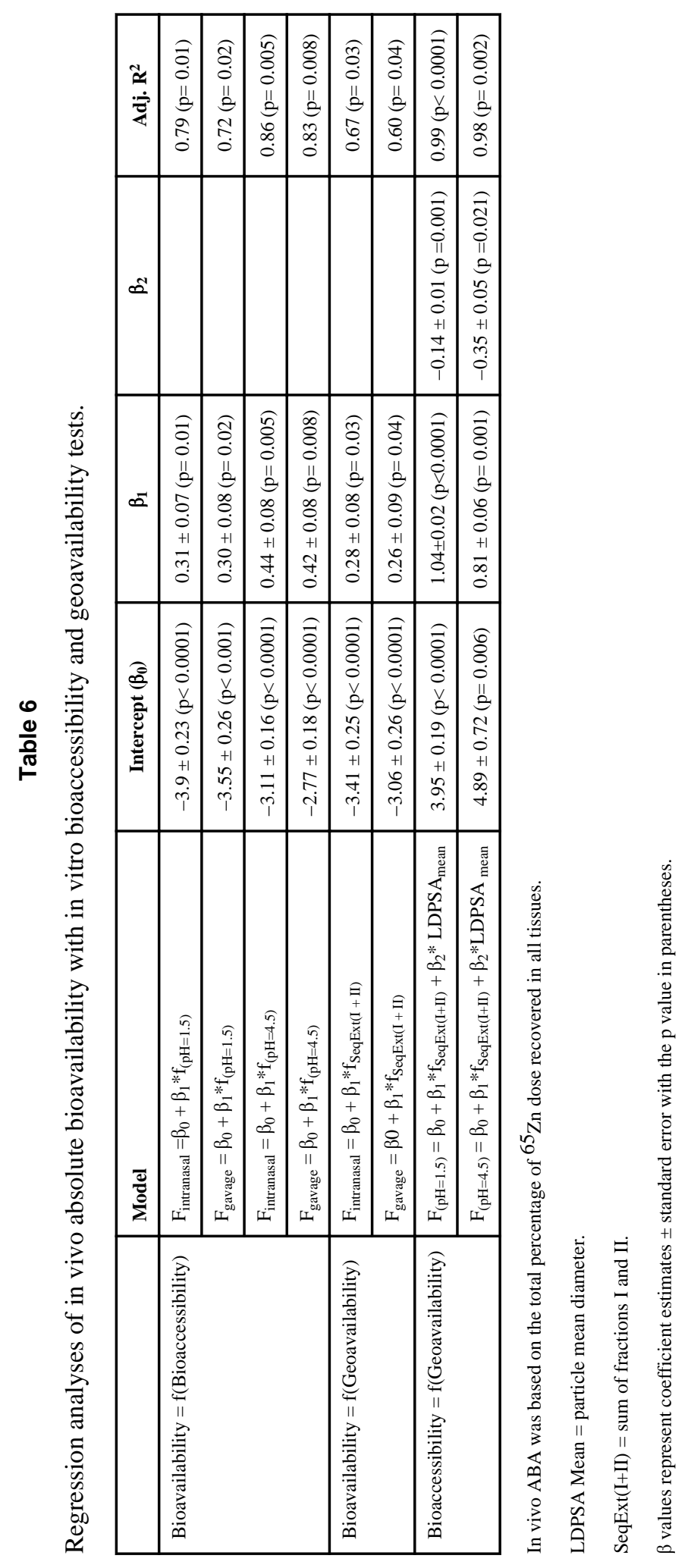

Environ Pollut. Author manuscript; available in PMC 2014 November 01. 